\title{
Çin Halk Cumhuriyeti’nin Çatışma Yönetimi Stratejisi Üzerinden Bir Dış Politika Okuması: 1990-2000 Yılları Arasında Çin-Kuzey Kore İlişkisi
}

\section{The Study of Foreign Policy on the Conflict Management Strategy of the Republic of the China: China-North Korea Relationship Between 1990-2000}

\author{
Yusuf Çınar a,* \\ ${ }^{a}$ Dr. Öğr. Üyesi, Bitlis Eren Üniversitesi, İ.İ.B.F. Uluslararası İlişkiler Bölümü, 13000, Bitlis/Türkiye. \\ ORCID: 0000-0002-8617-0267
}

\section{MAKALE BILLGİSI}

\section{Makale Geçmişi:}

Başvuru tarihi: 02 Haziran 2017

Düzeltme tarihi: 06 Temmuz 2017

Kabul tarihi: 12 Temmuz 2017

\section{Anahtar Kelimeler:}

Çatıșma Yönetimi

Çin Halk Cumhuriyeti

Kuzey Kore

Stratejik Kültür

\section{ARTICLE INFO}

\section{Article history:}

Received 02 June 2017

Received in revised form 06 July 2017

Accepted 12 July 2017

\section{Keywords:}

Conflict Management

People's Republic of China

North Korea

Strategic Culture
ÖZ

Çatışma, devletler arası ilişkilerde sıklıkla yaşanılan bir durumdur. Çatışmanın iyi yönetilmesi taraflara kazançlar sağlayabilir. Bu bağlamda Çin Halk Cumhuriyeti Asya kıtasının en önemli güçleri arasındadır. Nitekim Çin'in çatışma yönetim stratejisi Çin dış politikası parametreleri ile çoğu zaman örtüşmektedir. Bu çalışma Soğuk Savaş sonrasında 1990-2000 yılları arasında Kuzey Kore ile geliştirmiş olduğu dış politika stratejisini çatışma yönetimi stratejisi bağlamında değerlendirmeyi amaçlamaktadır. Çin'in bölge devletleri ile geliştirmiş olduğu çatışma yönetimi stratejisi Çin'i bölgede güçlendirmiştir. Bu çalışma Çin'in çatışma yönetim stratejisinin gelişimini ele almaktadir.

\section{Giriş}

Çatışmanın iyi yönetilmesi tarafların en zararla kurtulmalarını sağlayabilir hatta olumlu sonuçlar dahi yaratabilir. Çatışmanın kötü yönetilmesi ise, kayıpları arttırabilir veya tamiri mümkün olmayan sonuçlar doğurabilir. Bu sebepledir ki Galtung, çatışmayı kriz ve firsatlar toplamı olarak tanımlamaktadır (Galtung, 2007: 19). Çatışma kavramı, gelişimi itibariyle olumsuzluklar üzerine kuruludur. Çatışma en basit tanımı ile kavga, saldırganlık ve korku anlamına gelmektedir (Akyeşilmen, 2013: 19). Çatışma kavramının literatürde birçok tanımı yapılmasına rağmen ortak bir tanımda fikir birliğine varılamamıștır. UNESCO'ya göre çatışma, insan zihninde başlamaktadır ve yine barış, insan zihninde inşa edilmektedir (Unesco Constitution, 2012). Bu bağlamda Waltz 1959 yılında yazmış olduğu Man, The State and War (İnsan, Devlet ve Savaş) adlı eserinde savaşın sebeplerine dair üç türlü analiz düzeyi üzerinde yoğunlaşmıştır: (i) birey, (ii) devlet, (iii) sistem. Bu bağlamda çatışmanın aktörleri kişi, millet veya devlet olabilmektedir (Burchill vd., 2009: 36; Çınar, 2016: 87). Bu çalışma Çin Halk Cumhuriyeti ve Kuzey Kore diş

\footnotetext{
* Sorumlu yazar/Corresponding author.

e-posta: ycinar86@hotmail.com
} 
politika ilișkilerinde ki çatışma unsurunu devlet düzeyinde ele almaktadır.

Çin çatışma yönetimi felsefesinde çatışma, mao-dung kelimesi ile ifade edilmektedir. Mao dung, mantıken uyumsuz, karşılıklı olarak zitlık içinde anlamına gelmektedir. Mao dung doğuda "çelişki" anlamına gelirken, Batı literatüründe çatışma olarak ifade edilmektedir (Locke, 2007: 6). ${ }^{1}$ Küreselleşme çağının başlangıcı olarak kabul edeceğimiz Soğuk Savaş sonrasında Çin Halk Cumhuriyeti'nin Kuzey Kore politikasının sağlıklı bir şekilde analizinin yapılabilmesi için Çin'in çatışma yönetim stratejisinin belirlenmesi çok önemli bir yöntemdir. $\mathrm{Bu}$ bağlamda Çin Halk Cumhuriyeti (ÇHC) bölge ülkeleri ile yaşadığı çatışmalarda iletişim kanallarını iki önemli araç ile açmaktadır: i) Diaspora, ii) Çin kültürü.

Diaspora ve Çin Kültürü, Çin'in kendi bölgesinde yaşadığı çatışmaların iletişim kanallarını oluşturmaktadır (Chen ve Starosta, 1997: 1). Bununla beraber Çin'in çatışma yönetiminde beş önemli kavram hayati rol oynatmaktadır: uyum, karşılıklı ilişki, imaj, güç ve kaçınma. Çin toplumsal tabanın en önemli yapı taşlarından birisi uyumdur. Karşılıklı ilişki ise toplum grupları ve kişiler arasındaki ilişkiyi ifade etmektedir. Toplum grupları ve kişiler arasında iletişim kanallarının açık olması uyum kriterinin en önemli tamamlayıcı unsuru konumundadır. İmaj ise, çatışma koşullarında karşı tarafın ikna edilmesi hususunda çok önemli rol oynamakta başka bir ifade ile prestij anlamına gelmektedir. İmaj ve karşılıklı ilişki ilkesi uyum kavramı içerisinde bütünlüğü sağlamaktadır. Çin stratejik kültürünün oluşmasında önemli bir unsur olan Konfüçyus felsefesi, Çin çatışma yönetiminin de önemli bir parçası konumundadır. $\mathrm{Bu}$ bağlamda kıdem yani hiyerarşi Çin çatışma yönetimine Konfüçyus felsefesinin katkısı konumundadır (Oetzel ve Ting-Toomey, 2006: 556).

Kuzey Kore ile ÇHC ilişkilerinin yeniden inşa dönemi olarak tanımlayabileceğimiz 1993-2000 yılları arasında ÇHC başkanlığını yürüten Jiang Zemin 73 yaşında başkan olmuştur. Bununla birlikte otorite, kıdemi tamamlayan Çin çatışma yönetiminin diğer önemli unsuru konumundadır. 1990-2000 yılları arasında yaşlı bir başkana sahip olan ÇHC, başkanın kıdemine bir saygı olarak otoritesinin kabul edilmesini babanın ailedeki rolüne benzetilmekte ve sorgusuz olarak kabul edilmesini öngörmektedir (Oetzel ve Ting-Toomey, 2006: 7). Çin, çatışma yönetimi stratejisi arasında yer alan kaçınma ilkesi düşmandan korkulduğu anlamına gelmemektedir aksine başarıya ulaşılması için uygulanması gereken bir strateji olarak ifade edilmektedir. Kaçınma ilkesinin arka planında emniyet, uzlaşma, uygun ortam ve intikam korkusu yer almaktadır (Locke, 2007: 8). $\mathrm{Bu}$ bağlamda Çin ve Rusya'nın yaşamış olduğu sınır sorunları neticesinde iki tarafin 1992 yılında antlaşmaya varması, Çin'in çatışma yönetimi stratejisi için örnek verilebilir. Mao döneminde Çin, SSCB ile savaşın eşiğine gelmişken sonrasında kaçınma stratejisi uygulamıştır. Soğuk Savaş Sonrasında ise taraflar için uygun ortamın yaratılması ile sorun, uzlaşma ile çözmüştür (Akman, 2015: 311).

Çin, sahip olduğu nüfusu ve ekonomik gücü ile 21. yüzyılın en güçlü devletleri arasındadır (CIA, 2017). ${ }^{2}$ Çin, Soğuk Savaş'ın hemen sonrasında bölgesinde istikrarsızlık unsurları ile karşı karşıya kalmıştır. Bu bağlamda bu çalışma, 1990-2000 yılları arasında Çin-Kuzey Kore ilişkilerini ele almaktadır. İlk olarak çalışmamız stratejik kültürün Çin çatışma yönetimi stratejisine etkisini incelemektedir. İkinci olarak bu çalışma, Soğuk Savaş sonrasında Çin dış politikasının temel parametrelerini ortaya koymaya çalışmaktadır. Daha sonra ise Çin çatışma yönetimi stratejisinin ÇHC-Kuzey Kore dış politika ilişkilerine nasıl etki yaptığı ele alınmaktadır. Özetle bu çalışma, Çin çatışma yönetimi stratejisinin, Soğuk Savaş sonrasında değişen Çin dış politika parametreleri çerçevesinde Çin'in Kuzey Kore dış politikasına etkisini analiz etmektedir.

\section{2. Çin Çatışma Yönetimi Stratejisinin Tarihsel Gelişimi ve Stratejik Kültürün Buna Etkisi}

Çin medeniyeti geçmişten günümüze kadar gelmiş kadim bir medeniyettir. Çin'in devlet yönetimi, dış dünyaya nasıl davranacağına yönelik bazı ilkeler geliştirmiştir. Bu noktada Ming Hanedanlığı dönemi, devlet geleneğinde günümüze kadar gelecek bazı etkiler bırakmıştır. Ming Hanedanlığı 1368-1644 yılları arasında Çin stratejik kültürünün temelini oluşturmuştur (Johnston, 1998: 10). Stratejik kültür kavramını ilk kez 1977 yılında Jack Snyder kullanmıştır. Snyder stratejik kültürü, düşüncelerin, duygusal tepkilerin ve geleneksel davranış modellerinin toplamı olarak tanımlamıştır (Akçadağ, 2013). Stratejik kültür içerisinde birçok unsuru barındırmaktadır. $\mathrm{Bu}$ unsurlar şunlardır (Johnston, 1998: 12) : teknoloji, coğrafi yap1, örgütsel kültür, tarihsel stratejik uygulamalar, politik kültür, milli karakter, politik psikoloji, ideoloji, uluslararası sistem. Bu unsurlar, stratejik kültürün içeriğini inceleyen bilim adamlarının algılayışına göre değişebilmektedir. $\mathrm{Bu}$ unsurlara yeni unsurlar eklenebildiği gibi, bazı unsurlar ise, stratejik kültür tanımı içerisinden çıkartılabilmektedir.

Sun Tzu'nun yazmış olduğu Savaş Sanatı adlı kitap, Çin'in stratejik kültürü hakkında geniş bilgi vermektedir. Savaş Sanatı adlı kitapta; düşmanın stratejisini bozmada ve düşmanı alt etmede en önemli stratejinin düşmanın stratejisine saldırmak olduğu vurgulanmaktadır (Sun-Tzu, 2016: 52). Bu bağlamda Çin'in stratejik kültürü, güvenlik endekslidir denebilir (Segal, 1985: 180). Mao ile birlikte Çin stratejik kültürünün güvenlik konusunda daha hassas bir yapıya dönüştüğü söylenebilir (Dellios, 1994: 5). Dolayısıyla bu stratejik kültüre göre Çin bir sosyalist devletti ve emperyalistlere karşı her daim savaşa hazır olmalıydı (Dellios, 1994: 4). Bu bakış açısı Çin'in Güney Çin Denizi ve Japonya politikalarının şekillenme süreçlerinde etkili olmuştur denebilir.

Stratejik kültür, karar alma sürecine etki edebilmektedir. Stratejik kültür, semboller ve metaforlardan oluşmaktadır (Johnston, 1998: 36). Çin stratejik kültürü iki temelde şekillenmektedir. Parabellum stratejisi ve KonfüçyusMencian stratejisi Çin'in stratejik kültürünün temelini oluşturmaktadır. Parabellum (saldırgan) stratejisi, genellikle şiddet ve ofansif stratejiyi, statükocu ve uzlaşmacı stratejinin önüne koymaktadır. Bu paradigma, çevrenin tehlikeli olduğunu ve diş çevrenin düşmanlardan oluştuğunu belirtir. $\mathrm{Bu}$ strateji, dışarıdaki tehditlere karşı mücadele etmenin gerekli olduğunu vurgular. $\mathrm{Bu}$ paradigmaya göre, devlet güvenliğini tehdit eden düşmana karşı şiddet uygulanması kaçınılmazdır (Johnston, 1998: 155). Çatışmacı bir stratejik kültür, Çin çatışma yönetimini şiddet endeksli yapabilmektedir. Parabellum stratejisi, Çin diş politikasında dönem dönem kendini hissettirmiştir. Savaş dönemi stratejisi olarak da bilinen parabellum stratejisi daha saldırgan diş 
politika anlamına gelmektedir. Mao'nun özellikle Kore yarımadasına yapılan Batı yanlısı müdahale ile birlikte dış politika anlayışını daha da sertleştirdiği iddia edilebilir (Kennedy, 2012: 264). Konfüçyus-Mencian felsefe ise Çin çatışma yönetiminin daha çok diyalog yoluyla ilerlemesine yardımcı olmuştur. Konfüçyus-Mencian felsefe Çin çatışma yönetimi stratejisinin temeli olmuştur.

Konfüçyus-Mencian bakış açısı yardımseverliği, cömertliği, hak etmeyi, erdem ve iyi devlet yönetimini vurgulamaktadır. Konfüçyus-Mencian bakış açısı ülkenin iç bütünlüğüne önem vermekte ve iç isyanların cezalandırılması gerektiğini savunmaktadır. Nitekim Çin çatışma yönetim stratejisi uyum ilkesi üzerine inşa edilmiştir. Bu unsurlar, KonfüşyusMencian devlet güvenliğinin temelini oluşturmaktadır. Konfüçyus-Mencian paradigması, şiddete zorunlu olmadığ sürece başvurulmamasını önermektedir. $\mathrm{Bu}$ strateji, düşmanı silah zoru ile değil, yumuşak dille etkisiz hale getirmeyi önermektedir (Johnston, 1998: 155). Çin stratejik kültürü uzlaşıyı bir adım öne çıkarmaktadır. Bu bağlamda otorite Çin çatışma yönetimi stratejisine aileden yani babanın egemenliğinden gelmektedir. Babanın otoritesine karşı aile üyelerinin başkaldırması hem uyumsuzluk hem de itaatsizlik anlamına gelmektedir. Bu bağlamda çatışma yönetiminin başarısız olduğu siyasi dönemlerde Çin, güvenlik endeksli dış politikaya yönelmiş ve şiddet uygulamaktan çekinmemiştir. Bir nevi düşmana karşı ceza anlamına gelen Parabellum stratejisi, Çin stratejik kültürü içerisinde Ming hanedanlığ1 döneminde aktif olarak uygulanmıştır. Bu dönemde Kuzeyde Çin Hanedanlığı'nı tehdit eden Moğollara karşı şiddet uygulanmaktan kaçınılmamıştır. ÇinMoğol çatışmasını o dönemde kaydeden Çinli yazarların belirttiği gibi, bu dönemde devletin güvenliğinin tehlikede olduğu vurgulanmış ve firsat bulunduğunda tehdidin yok edilmesi gerektiğinin altı çizilmiştir. (Swope, 2016: 33-36).

Konfüçyus-Mencian stratejik kültürü, Çin çatışma yönetimini etkilemekle kalmamış Çin hükümdarlarının yapmak istediklerini halka anlatmakta bir araç olmuştur. Başka bir ifade ile tarihsel süreçte Çin çatışma yönetimi stratejisi Çin hükümdarının halkı ile arasında köprü görevi görmüştür. Buradan hareketle Çin çatışma yönetim stratejisinin toplumsal temelli olduğu söylenebilir. Parabellum stratejisi, devletin diğer devletlere karşı uygulayacağı güvenliği ilgilendiren stratejik adımların temelini oluşturmaktadır. Her iki stratejiyi karşılaştırmak gerekirse tarihsel süreçte Parabellum stratejisi "yüksek politika" sınırları içerisinde kalmış, toplumdan uzak bir şekilde gelişmiştir.

\section{3. Çin Halk Cumhuriyeti'nin Dış Politika Parametreleri}

ÇHC dış politikası, Mao Zedong döneminde bazı ilkeler çerçevesinde gelişmiş; ideoloji ve güvenlik endişesi ön planda olmuştur. $\mathrm{Bu}$ dönemde ÇHC, yaşadığı diş politika sorunlarında çatışmayı yönetmekten ziyade, sorun yaşanan ülke ile savaşmaya yönelik bir diş politika izlemiştir. Mao dönemi dış politikasının temel noktalarını Allen Whiting, şu şekilde belirtmektedir (Zhao, 1996: 49; Varrall, 2015: 7):

(i) Aktif caydırıcılığı savunmak: ÇHC kendisini bu dönemde güvende hissetmemektedir ve ülkenin bütünlüğünü kaybedeceği korkusunu taşımaktadır. En büyük tehlikenin de sınır komşularından geleceğine inanmaktadır. SSCB ve Japonya'nın Çin'i işgal edebileceği kaygısı Çin'in komşuları ile ilişkilerini etkilemiştir (Nathan ve Scobell, 2014: 17).

(ii) Çin, iç bütünlüğünde yaşanacak bir kopuşun veya isyanın, güçlü düşmanlarının Çin'e saldırmasına sebep olacağını düşünmektedir (Ko vd., 2018).

(iii) ÇHC için en iyi caydırıcı unsur kavgacı olmaktır:

- ÇHC'nin silah kullanabileceği imajını yaratmak.

- Diplomasi, düşmanın ÇHC'yi aşağılaması halinde uygulanır.

- ÇHC birinci denemesinde başarıya ulaşamıyorsa, tekrar denemelidir.

(iv) Doğru zamanlama esastır:

- Bir tehdit algılandığında tehdit unsuru uyarılmalıdır.

- ÇHC, kendisinin hareketini, düşmanın seçeceği seçeneğe göre yönlendirmelidir.

ÇHC dış politikası Deng Xiaoping 'in yönetime gelmesi ile birlikte dış politika bazı yeni ilkeler çerçevesinde yürütülmüştür. Deng, oluşturduğu bu dış politika ilkelerini 28 karakter stratejisi olarak adlandırmıştır. Deng dönemi dış politika kriterleri ise Mao'nun aksine daha çok çatışma yaşanan sorunları çatışma yönetim stratejilerine uygun olarak yönetmeye dair olduğu iddia edilebilinir. 28 karakter stratejisi; Tiannanmen olaylarının, Sovyetlerin çöküşünün ve Avrupa ile ilişkilerin geliştirilmesinin izlerini taşımaktadır. 28 karakter stratejisi, altı aşama içermektedir (Zhao, 1996: 54; Narayanan, 2006; Cheng ve Zhang, 2009):

(i) İzle ve gelişmeleri sakince analiz etmek, Deng dönemi Dış Politikasının çatışma yaşanan ülke ile diyalog yolunu açan en önemli ilkesi konumundadır.

(ii) Kendine güvenmek ilkesi Çin çatışma yönetiminin imaj kavramı ile bütünleşmektedir.

(iii) Güvenlik pozisyonu ise Çin çatışma yönetim stratejilerinden otoriteye denk gelmektedir.

(iv) Alçak profili korurken iyi olmak aşaması, Çin çatışma yönetim stratejisi bağlamında karşılıklı ilişkilerin korunması ve iletişim kanallarının açık tutulması anlamina gelmektedir.

(v) Kapasiteni gizlemek aşaması, çatışma yaşanan ülkelere karşı doğrudan güç kullanmak yerine Çin Çatışma yönetimi stratejisinin imaj ile bütünleşmiş bir gücü ifade etmektedir.

Katkı yapmak aşaması Çin çatışma yönetim stratejilerinden uyum ilkesi ile bütünleşmektedir. Diğer beş aşamanın bir sonucu olarak çatışmadan olumlu bir sonuç almayı ifade etmektedir.

ÇHC'nin dış politikası, Deng ile beraber, köklü bir değişim geçirmiştir. Yukarıdaki dış politika prensiplerinden anlaşılacağı gibi Çin, 1990 sonrası süreçte Sosyalizmin bayrağını, lider olarak taşımak istememiştir. Deng, ÇHC dış politikasında ideolojik olarak Komünizm'e körü körüne bağlı olmak yerine, pragmatizm çerçevesinde Çin'in menfaatlerini ön plana almıştır. ÇHC dış politikası, dış dünyadan dışlanmak istememektedir. Aksine Çin, dünya ile 
bütünleşmek ve çatışma yaşamak istememektedir. Bu noktada Çin çatışma yönetimi stratejisi başka bir ülke ile yaşanabilecek çatışmanın önüne geçmeyi hedeflemekle birlikte, çatışmanın yaşanması halinde ise iletişim kanallarının açık kalmasını hedeflemektedir. Bundan dolayıdır ki, Soğuk Savaş sonrasında Çin'in dış politikada uluslararası örgütler ile iyi ilişkiler kurmak istemesi ana hedefi olmuştur (Xie, 2011: 85).

Dünya 21.yüzyıla girerken Çin, global sisteme endekslenmeye çalışmıştır. Bunu yaparken de anahtar unsur olarak iç istikrarı vurgulamıştır (Zhao, 1996: 248), (Kim, 2017). Çin'in kendi içinde uyumun devam etmesi dış politikasında "uyumun" temeli olmuştur. ÇHC dış politikası komşular arasında ilişkilerin geliştirilmesine ayrıca önem verilmiş, Kuzey, Güney, Merkezi Asya ve Rusya ile karşılıklı ilişkilerini geliştirmiş ve belli bir güvenlik statükosu oluşturmuştur. 14. Komünist Parti Milli Kongresi'nde ÇHC'nin kurulduğundan bu yana en iyi dönemini yaşadığı vurgulanmış: ÇHC'nin güvende olduğu izlenimi verilmiştir. Dolayısyla ÇHC'nin kongre neticesinde reform yanlısı ve açık politikaların izlemesinin güvende olmanın vermiş olduğu rahatlıktan kaynaklandığ söylenebilir (The 14th National Congress, 2016).

Yukarıda ÇHC dış politikasının ve toplumsal yapının ana karakteristik özelliklerinden hareketle Çin çatışma yönetimi stratejisi üzerinden bir değerlendirilme yapılmıştır. $\mathrm{Bu}$ bağlamda çalışmanın diğer bölümünde, ÇHC dış politikasındaki bu yönelimlerden hareket ederek, ÇHC ve Kuzey Kore diş politika ilişkisini ele almaktadır. Bu bölümde Çin'in oluşturmaya çalıştığı bölgesel güvenlik sisteminin Kuzey Kore ile ilişkilerine yansıması, Çin'in çatışma yönetimi stratejisi çerçevesinde değerlendirilecektir.

\section{4. Çin Halk Cumhuriyeti Dış Politikasında (1990- 2000): Kuzey Kore}

Kore yarım adası, ÇHC'nin geçmişten bu yana en önemli ilgi alanlarından biri olmuştur. Kore yarımadası, 19.yüzyılın ilk çeyreğinden günümüze kadar Pasifikte istikrarsızlığın simgesi haline gelmiştir. Soğuk Savaş döneminde Kore yarımadası ideolojilerin ve büyük güçlerin mücadele alanı olmuştur. 19. yüzyılın son çeyreğinde ise ÇHC ve Kuzey Kore arasındaki ilişki, bu iki yakın devletin politik kültürlerinin analizini yapma fırsatı vermektedir. $\mathrm{Bu}$ bağlamda Kuzey Kore ve ÇHC'nin birbirlerine karşı bakış açısını bilmek, 1990'lı yıllardaki bu iki devlet arasındaki dış politik süreci tahlil etmeyi kolaylaştırabilir.

Çin, Kore yarımadası ile geçmişte çok sıkı ilişkilerde bulunmuştur. Çin ile Kore Devleti arasında imzalanan 1637 tarihli anlaşma ile Kore yarımadası, Çin tarafindan vergiye bağlanmıştır. Çin, Kore yarımadasına hâkim olmaya çalışmıştır. 19. yüzyılda Kore yarımadasında hâkim bir güç haline gelen Çin, bölgede etkili bir yönetim sergilemiştir. Bu dönemde, Kore Kralı, Çin hükümdarı tarafından "köle kral" olarak adlandırılmıştır. Kore Kralı, 1871 yılında Pekin'i ziyaret etmiş ve bu ziyarette Çin'in büyük imparatorluk olduğunu vurgulamıştır (Rockhill, 1889: 4). Çin, Kore adasındaki siyasi otoriteyi kontrolü altında tutmuş ve Kore yarımadasına savaş araçlarının ticaret yoluyla girmesini engellemiştir. Çin ve Kuzey Kore arasındaki çatışmanın temeli dikkate alındığında çatışmanın asıl sebebinin Çin'in Asya Kıtası üzerindeki hegemonya kurma isteğinden kaynaklandığı söylenebilir. Çin'in bölge ülkelerini kendisinin bir parçası olarak görmesinin kendisini Kore ile bir aile gibi görmesine sebep olduğu vurgulanabilir. Çin'e göre, bu büyük ailenin başı ÇHC'dir. Çinlilere göre, Kore yarımadasındaki halk, Çinlilerin kardeşidir (Rockhill, 1889: 18)

ÇHC'nin kurulmasından hemen sonra 25 Haziran 1950'de Kore Savaşı başlamıştır. Hanry Truman, Birleşmiş Milletler 'in operasyonunu desteklemesi sonucu savaş uluslararası bir boyut kazanmıştır. Bu durum, ÇHC tarafından ülke güvenliğini tehdit ettiği sebebiyle, Kore'ye bir milyon gönüllü Çinli militan gönderilmiştir (Faust ve Kornberg, 1995: 162). Üç yıl süren kanlı savaş sonucunda iki devlet ortaya çıkmıştır: Kuzey Kore ve Güney Kore. Çin, Kuzey Kore ile 11 Haziran 1961 tarihinde dostluk ve işbirliği antlaşmasını imzalamıştır. Kuzey Kore bu antlaşmayı adada kendisini güvenli hissetmek için imzaladığını vurgulamıştır. İmzalanan bu antlaşma ile Kuzey Kore ve Çin ortak düşman olarak ABD’yi hedef göstermişlerdir. Dolayısıyla, bu iki devlette güvenlik endeksli dış politika takip etmiştir (Scalapino, 1963: 38).

Kuzey Kore'nin lideri Kim II Sung, Kuzey Kore'nin başına 1948 yılında geçmiş ve Temmuz 1994 yılında ölmüştür. Kim II Sung, Kuzey Kore'de siyasi otoriteyi tamamen kontrol altına almış; deyim yerindeyse Kim II Sung, Kuzey Kore halkının kültürü, politikası kısaca her şeyi olmuştur. Kim II Sung, kendi modellerinde Sosyalizmi uygulayacaklarını belirtmiştir. Kim II Sung, Juche düşüncesi çerçevesinde Kuzey Kore'yi şekillendirmiştir (Kim, 1996: 63). Kim II Sung, Amerikan yaşam şeklini kendisine en büyük düşman olarak benimsemiştir (Scalapino, 1963: 37). Komünist ideolojinin, Soğuk Savaş’tan mağlubiyet ile ayrılması ve Kim II Sung'un ölümü sonucu, Kuzey Kore yönetiminin devrilebileceği gündeme gelmiştir.

Çin'in Kore yarımadasına yönelik dış politikasını 1990 sonrasında iki unsur belirlemektedir: i) Kuzey ve Güney Kore'nin Çin ile ilişkileri, ii) ABD'nin Çin güvenlik bölgesindeki askeri varlığı. Bu iki unsur Çin'in soğuk savaş sonrasında Kore yarımadasına yönelik dış politikasının temelini oluşturmuştur (Wang: 1999: 183). Kore yarımadasında Soğuk Savaş esnasında oluşmuş olan statüko, Çin Halk Cumhuriyet'i için istikrarı temsil etmektedir. Bu statükonun değişmesi, ÇHC'nin güvenliğini tehdit etmektedir. ÇHC, Kuzey ve Güney Kore'nin birleşmesinin aşamalı olması gerektiğini vurgulamakta ve bu birleşmenin statükoyu bozmaması gerektiğini belirtmektedir (Wang, 1999: 174). Çatışmalar Thomas Hobbes'in belirttiği gibi fikir ayrılıklarının dile getirilmesiyle gerçekleşmektedir (Tekin, 2013: 88). ÇHC'in Kore'nin birleşmesini istemesi, ÇHC ve Kuzey Kore arasında ilişkilerin gerilmesine sebep olmuştur. Fakat ÇHC, Kuzey ve Güney Kore arasında diyalog sürecinin başlamasını istemiştir. $\mathrm{Bu}$ bağlamda küresel gelişmelerde bu sürecin devam etmesine önemli derecede etkisi olmuştur. NATO'nun Yugoslavya operasyonu esnasında 8 Mayıs 1999 tarihinde ÇHC büyükelçiliğini yanlışlıkla bombalaması, Kuzey Kore'nin kendisine bir operasyon yapılabileceği korkusuna kapılmasına sebep olmuştur. $\mathrm{Bu}$ bağlamda ÇHC Cumhurbaşkanı Jiang Zemin ile Kuzey Kore'nin iki numarası Kim Yong Nam arasında bir toplantı gerçekleşmiştir (Zhao, 2006: 20). ÇHC, Güney Kore ve Kuzey Kore arasında izlediği denge politikasına devam 
etmiş, taraflar arasında iletişim kanallarının açık kalması için çabalamıştır.

ÇHC, büyük güçlerin yarımadada oluşturmuş oldukları dengenin farkındadır. Çinli analizciler, Asya'nın istikrarının Asya'nın Kuzeyindeki dengeye bağlı olduğunu vurgulamaktadır. $\mathrm{Bu}$ bağlamda Kore yarımadasındaki denge; Amerika, Japonya, Çin ve Rusya arasındaki ilişkiye bağlı olduğu belirtilmektedir. Kore yarımadasındaki bu dörtlü denge, ÇHC'in Kore yarımadası güvenlik sistemini meydana getirmektedir. ÇHC, yarımadadaki bu dengenin bozulmasından korktuğu için, Soğuk Savaş sonrasında Güney Kore ile diplomatik ilişkileri 1992'de kurmuş ve Kuzey ve Güney'e eşit davranmayı öneren "eşit mesafe" diplomasisini benimsemiştir. Kuzey Kore lideri, Hwang Chang Yop 1997 Şubat'ında Beijing'i ziyareti esnasında Çin'in iki Kore politikasını eleştirmiştir (Lee, 2001: 321).

ÇHC, ABD’nin adadaki bu statükoyu koruduğu sürece yarımadada pasif davranmaya devam edebilir. Çünkü ÇHC Dışişleri Bakanı, Soğuk Savaş sonrasında Çin'in kendisini ilk defa güvenli hissettiğini belirtmiştir. ÇHC ve Rusya arasında bulunan 39 yıllık dostluk antlaşması ve Çin'in Güney Kore ve Kuzey Kore ilişkilerini geliştirmesi, kendisini güvenli hissetmesini sağlamıştır. $\mathrm{Bu}$ bağlamda Çin, Deng döneminde dış politika prensibi olarak, büyük güçlerle doğrudan ada üzerinde karşı karşıya gelmemeye özen göstermektedir (Wang, 1999: 172).

ÇHC, Tienman olayları sebebiyle dış dünya ile olan ilişkileri kopma noktasına gelmiş, sonraki süreçte ise, dış politikasını dış dünyaya açmak zorunda kalmıştır. Çin yarımadada oluşturduğu bölgesel güvenlik sistemi, Tienman olayları esnasında çökmemiştir. ÇHC, bölgesel güvenlik sistemini sınırındaki ülkelere göre oluşturmuştur. ÇHC'ye karşı Tiennanmen olayları sebebiyle kendi bölgesinde Japonya dışında tepki gösteren ülke olmamıştır (Shambaugh, 20042005: 71). ÇHC, bu tarihten itibaren dış politikada açık kapı politikası uygulamaya başlamıştır (Dassu ve Saich, 1992: 164).

ÇHC, dış politikada kendini dış dünyaya açmadan önce Kuzey Kore'yi kendine muhtaç bir ülke olarak görmüştür. $\mathrm{Bu}$ bakış açısı, Kuzey Kore'de ÇHC'nin Soğuk Savaş sonrasında bölgede etkisini kaybedeceği korkusu uyandırmıştır. Soğuk Savaş'ın bitişi ile ABD tek süper güç olarak Kuzey Kore ile yoğun ilişsiler kurmaya başlamıştır. $\mathrm{Bu}$ süreç ÇHC'yi endişelendirmiş ve bölgede istikrarın bozulacağı korkusu ortaya çıkmıştır (Garret ve Glaser, 1995: 542). ÇHC, ideolojik çatışmanın bittiğini ve yenidünya düzenin kurulmakta olduğunu anlayınca, Kuzey Kore'ye yönelik dış politikasını da değiştirmiştir. Nitekim Kuzey Kore ile Çin'in kan bağı olmasına rağmen ÇHC, Kuzey Kore ile ilişkilerinde fayda-maliyet analizine dayalı bir dış politika izleme gayreti içinde olmuştur (Garret ve Glaser, 1995: 544). Çin-Kuzey Kore ilişkilerinde ÇHC için ideolojinin etkisi devam etmekle birlikte Soğuk Savaş dönemindeki kadar etkili konumda olmamıştır. Bölge ülkeleri için Kore yarımadası sıradan bir toprak parçası değildir. Çünkü Kore yarımadasını önemli yapan buradaki ekonomik ve fiziksel özellikler değildir, büyük ölçüde yarımadanın önemi ideolojiler tarafindan belirlenmektedir.

ÇHC, 1997-2001 yılları arasında bölgesel güvenliğe çok önem vermiştir. ÇHC, bölgesel güvenliğe katkıda bulunurken çoklu işbirliğini benimsemiş, bölgedeki ülkelerle ilişkilerini geliştirmeye önem göstermiştir. ÇHC, bölgesel güvenliğe şu şekilde katkıda bulunmaya çalışmıştır (Shambaugh, 2004-2005: 72): i) Bölgesel organizasyonlara katkıda bulunmak, ii) Stratejik ortaklık kurmak ve ikili ilişkiler geliştirmek, iii) Bölgedeki diğer ülkeler ile ekonomik bağları geliştirmek, iv) Bölgesinde kendini güvende hissetmek.

ÇHC'nin Kuzey Kore ile ilişkisi Çin'in Kore yarımadasına dair geçmişten gelen emperyalist emellerinden ziyade kendi sınır güvenliği çerçevesinde uluslar arası konjonktür dahilinde dönüşüme uğramıştır. Çin, Kore yarımadasına güvenlik endeksli bakmaktadır. Bu bağlamda ÇHC, Kuzey Kore'nin nükleer silah elde etme programını önlemeye yönelik uluslararası adımları desteklemiştir. Çin, Kuzey Kore'nin silah elde etmesi halinde bölgede istikrarın kaybolacağını iddia etmiştir (Garret ve Glaser, 1995: 528). Çinli uzmanlar, Kuzey Kore'nin Soğuk Savaş dönemindeki dostlarının yok olduğunu, şimdi Güney Kore'nin yükselişine karşı, Kuzey Kore'nin yeni bir dostluk modeli oluşturması gerektiğini belirtmiştir. Çinli uzmanlar, Kore'nin ekonomik reform yapmalarının şart olduğunu vurgulamışlar ve Kore'nin kendi tecrübelerinden yararlanabileceklerini belirtmiştir. Çinli uzmanlar, Kuzey Kore'nin kapitalist modele geçerken Çin'deki kapitalist modelin kopyasını almak yerine, Kuzey Kore karakterini taşıyacak şekilde bu tecrübeden yararlanabileceklerini vurgulamışlardır (Garret ve Glaser, 1995: 534).

ÇHC ve Kuzey Kore arasındaki dış politika sürecini analizi hususunda üç nokta önem arz etmektedir. İlk olarak, bu iki ülke arasındaki politik bağın (Komünizm) hala etkin mi yoksa etkin değil mi bunun bilinmesi gerekmektedir. İkinci olarak bu iki ülke arasındaki ekonomik ilişkilerin bağımlılığa mı dönüştüğü hususudur. Son olarak bu iki ülke arasındaki karşılıklı toplumsal ilişkinin devam edip etmediği hususudur (Ahn, 2002: 47).

Kuzey Kore komünist rejimi benimsedikten sonra, komünist rejime sahip Sovyet Sosyalist Cumhuriyetler Birliği (SSCB) ve ÇHC ile yoğun ilişkiler içine girmiştir. Kuzey Kore, SSCB ve ÇHC'yi ideolojik dostluğun dışında ekonomik bir nefes borusu olarak görmüştür. 1984 yılında SSCB'nin Kuzey Kore'ye ekonomik yardımı kesmesi sonucu Kuzey Kore büyük ekonomik sıkıntılar çekmeye başlamıştır. Kuzey Kore'nin ekonomisi 1990 yılında \% 13, 1991 yılında \% 5.2, 1992 yılında \% 7.6, 1993 yılında \% 4.3 küçülmüştür.(Kim, 1996: 64). Soğuk Savaşın bitmesi, Kuzey Kore ekonomisini olumsuz bir şekilde etkilemiştir. Bu süreç, Kuzey Kore'nin bölgede ekonomik ve "stratejik ortak" araması sonucunu getirmiştir denebilir.

Rusya'nın Soğuk Savaş sonrasında Güney Kore ile ilişkilerini geliştirmesi Kuzey Kore cephesi tarafindan tepki ile karşılanmıştır. Rusya'nın 1995 y1lında Kuzey Kore'den borçlarını ödemesini istemesi iki ülke arasındaki ilişkilerin daha da gerginleşmesini sağlamıştır. Bu dönemde Kuzey Kore ile Rusya arasındaki ticari ilişkiler bir önceki yıla göre 30 milyar dolar azalmıştır. Aynı dönemde Çin ve Kuzey Kore arasındaki ilişkiler ise, ÇHC Cumhurbaşkanı Jiang Zemin'in Kasım 1995 yılında Güney Kore'ye yaptığı ziyaret sebebiyle kopma noktasına gelmiştir. Kuzey Kore ile ÇHC arasındaki ticaret hacmi bir önceki yıla göre \% 19 azalmıştır.(Kim, 1996: 69-70). Kuzey Kore eski ideolojik dostları ile ekonomik ilişkilerini azaltması Kuzey Kore'yi başka devletler ile ilişki kurmaya zorlamıştır. 1995 yılından 
itibaren Kuzey Kore, SSCB ve ÇHC ile ekonomik ilișkilerinin zayıflamasına karşı, $A B D$ ve Japonya ile ekonomik ilişkilerini geliştirmeye çalışmıştır. Bunun ile birlikte, Kuzey Kore'nin ekonomisinin gittikçe kötüleşmesi Kuzey Kore'nin uluslararası örgütler ile işbirliğine gitmesi sonuncu getirmiştir. Kuzey Kore 1995 yılı itibariyle, on beş Avrupa Birliği üyesinin on üçü ile iyi ilişkiler kurmuştur. Kuzey Kore bu adımı ile dış dünya ile ilişkilerini normalleştirmek istediğini göstermiştir.

Kuzey Kore'nin ekonomik sıkıntı yaşaması Kuzey Kore halkını açlık sıkıntısı ile karşı karşıya getirmiştir. Bu süreç Kuzey Kore'nin iç istikrarını olumsuz etkilemiștir. Berlin Duvarının yıkılmasıyla Kuzey Kore'nin geliri yüzde otuz azalmıştır. Doğu Almanya'nın Batı Almanya'nın ekonomik refahına yenilmesi, Kuzey Kore'nin Güney Kore ile birleşeceği beklentisini yaratmıştır. $\mathrm{Bu}$ minvalde Kuzey Kore'nin iç istikrarsızlığı, Kuzey Kore'nin Güney Kore'nin hâkimiyeti altına girer korkusu Çin'i endişelendirmiş ve Kuzey Kore'nin çöküşüne, Çin'in izin vermeyeceği dillendirilmiştir (Garret ve Glaser, 1995: 539). Çin'in bu şekilde duyarlı davranmasının en önemli sebebi Çin çatışma yönetim stratejisinde aranması gerekmektedir. Çin çatışma yönetimi stratejisinde en önemli unsurlarından birisi de toplumun bir aile olarak görülmesidir. Çin Kore yarım adası ile birlikte bu bölgenin insanlarını aynı ailenin bireyleri olarak görmekte ve bu ailenin en büyük bireyi olarak kendisine sayg 1 duyulmasını ve otoritesinin kabul edilmesini istemektedir.

Kuzey Kore'nin toplumsal yapısı, Çin toplumsal yapısı ile benzerlikleri barındırmaktadır. Kuzey Kore'de toplumsal yap1, feodaliteye dayalıdır. Bu feodal yap1 Kuzey Kore Komünist rejiminin dayanak noktası konumundadır. 1997 yılında Kuzey Kore'nin yaşamış olduğu açlık krizi, Kuzey Kore'nin çökeceği endişesini daha da arttırmıştır. Kuzey Koreliler, Çinlileri akraba olarak görmeye devam etmiştir. Birçok Kuzey Koreli, 1997 yllında Çin'de yaşayan akrabalarından yiyecek yardımı almıştır. Çin'de yaklaşık 2 milyon Koreli yaşamaktadır. Bu bağ Çinliler ve Koreliler arasındaki bağı güçlendirmiştir (Zhao, 1996: 17). Kültürel yakınlık ÇHC ve Kuzey Kore arasındaki ilişkilerin toplumlar arası iletişim kanallarının açık kalmasını sağlamıştır. Öyle ki kültürel benzerlik Çin'in çatışma yönetim stratejisini güçlendirmiş, her iki toplumun kriz durumunda aynı şekilde düşünmesini sağlamış, Çin halkının Kuzey Kore halkına el uzatmasını tetiklemiştir. Çin çatışma yönetim stratejisinin kaçınma ilkesi Çin dış politikasının Kuzey Kore rejiminin devam etmesini öngörmektedir (Zhao, 1996: 27). Özellikle Kuzey Kore rejiminin çökmesi halinde milyonlarca Korelinin Çin'e göç edeceği ihtimali Çin'in Kuzey Kore rejiminin düşürülmesine yönelik eylemlerden kaçınmasına sebep olmaktadır.

Kuzey Kore vatandaşları, yönetimin baskısı altında kalmıştır. Kuzey Kore, ÇHC'nin Tianenmen olaylarından ders almıştır. Çünkü Tianenmen meydanında olaylarından önce Çin'de enflasyon \% 30 seviyesinde seyretmiş, Çin toplum ekonomik hoşnutsuzluğunu Tianenmen meydanında dile getirmiştir (Shi, 1990: 1192). Kuzey Kore, ideolojik baskılarını artırarak, Kuzey Kore halkının, gida yetersizliğinden dolayı isyan etmesini önlemek istemiştir. İki toplumun birbirine akraba toplumlar olması birbirlerine ılımlı siyasi tavırlar sergilemesini sağlamıştır. ÇHC, Kuzey sınırında yaşanan gıda hareketine müdahale etmemiştir
(Snyder, 2000-2001: 527). Cünkü Çin, Kuzey Kore’nin çökmesi halinde yarımadadaki istikrarsızlığın, Çin bölgesel güvenlik sistemini olumsuz etkileyeceğini öngörmüştür. Kuzey Kore için, Soğuk Savaş sonrasında Çin, ideolojik dostluktan öte istikrar unsuru olarak algılanmıștır. Çin ve Kuzey Kore siyasi yetkilileri, 1990'larda birbirlerine yönelik ziyaretlerde bulunmuşlardır. Özellikle Çin, 1998'de Kuzey Kore'nin enerji ve gıda sıkıntısı çektiğini görmüş ve Kuzey Kore'ye 2000 ton gida 30.000 ton motorin yardımında bulunmuştur (Ahn, 2002: 52). Kuzey Kore bu bağlamda Çin ile dostluk ilişkilerini geliştirmeye dönemde daha ağırlık vermiştir (Scalapino, 1963: 48). Bu süreç Çin çatışma yönetimi stratejisine göre bir bağımlılıktan daha çok imaj anlamına gelmekte bir bakıma Çin, kendi yumuşak gücünü Kuzey Kore üzerinde arttırmaya çabalamıştır (Sweda, 20032004: 36).

Kuzey Kore, askeri alana çok fazla kaynak ayırmıştır. Yaklaşık olarak 1992 yılı itibariyle bir milyar iki yüz milyon nüfuslu Çin, iki milyon askere sahipken otuz milyonluk Kuzey Kore, dokuz yüz otuz bin kişilik askere sahip olmuştur (Faust, Kornberg, 1995: 171). Bu dönemde, Kuzey Kore bölgesel istikrarı da olumsuz etkileyecek biyolojik silah ve kimyasal silah üretmiştir (Horward, 2004: 807). Kuzey Kore nükleer silah yapımına 1980'li yıllarda başlamıştır. Çin'in nükleer silahı 1964 yılında elde etmesi, Kuzey Kore'nin de nükleer silah yapımına Çin yardımı ile 1964 sonrasında yoğunlaşmasına neden olmuştur. Güney Kore'nin ekonomik olarak güçlenmesi karşısında Kuzey Kore bölgede kendisinin yalnız kalacağı korkusuna kapılmıştır. Başka bir deyişle Kuzey Kore nükleer silaha güvenlik sebebi ile yönelmiştir. Buna karşılık, Kuzey Kore'nin nükleer silahı Güney'i işgal etmek için geliştirdiği de iddia edilmektedir (Kang, 1995: 267). ABD, 1994 yılında Kuzey Kore'nin elde ettiği plütonyumu almak istemiş fakat Kuzey Kore bu öneriye sicak bakmamıştır (Oh ve Ralf, 1999: 294). Kuzey Kore bölgede Çin ile dostluğuna daha fazla önem vermektedir. Bu süreçte ÇHC, 21. yüzyıla girerken nükleer güce sahip bir Kuzey Kore'yi tehdit olarak görmemiştir. (Yavaş, 2017: 198).

Çin-Kuzey Kore ilişkilerinde 1990 sonrasında, Soğuk Savaş döneminin getirmiş olduğu alışılmış davranış biçimleri, terk edilmeye başlanmıştır. Çin, 1980'lerin Taoist dış politika anlayışını terk etmiş, uluslararası toplumla bütünleşme seçeneğini tercih etmiştir. Kuzey Kore ve ÇHC ilişkisi tamamen pragmatizme dayalı olarak evirilmiştir. Çünkü iki ülkenin de pasifikte çıkarları farklılık göstermektedir. Buna karşılık Güney Kore, Çin'in yapıcı politikasına ihtiyaç duymaktadır. Başka bir ifade ile bölgesel işbirliği çatışmaların sonlandırılmasında çok önemli bir role sahiptir. Fakat bu işbirliğinin niteliği çatışmanın dönüşümünü olumlu veya olumsuz etkileyebilmektedir (Deutsch, Coleman \& Marcus, 2006: 24). ÇHC'nin Kuzey Kore politikası karşılıklı dış politik hedeflerden ziyade Çin'in belirlediği hedefler doğrultusunda ilerlemektedir. Bu bağlamda ÇHC'nin Kuzey Kore dış politikası negatif işbirliği örneği konumundadır denebilir.

\section{Sonuç}

Çin çatışma yönetimi stratejisi geçmişten gelen tarihsel birikimin sonucu şekillenmiştir. Mao döneminde çatışma yönetim stratejisi dış politikada daha az etkili olmuştur. $\mathrm{Bu}$ dönemde ÇHC'nin dış politikası güvenlik endeksli olmuş bir 
nevi çatışmanın asil unsuru kendisi olmuştur. Mao döneminde Çin stratejik kültürü, güvenlik paradigması çerçevesinde dış politikayı etkilemiştir. Parabellum strateji, Çin stratejik kültürünün çekirdek unsurları arasındadır. Çin'in parabellum stratejisi Kore yarımadasının ikiye bölünmesinde etkili olmuştur. Parabellum stratejisi Mao dönemi dış politikasının en etkili öznesi konumundadır. Komünist ülkelere lider olma isteği, Çin'in Mao döneminde sınır güvenliğine daha fazla önem vermesi sonucunu getirmiştir. Mao döneminde saldırgan bir dış politika izlemek, Çin'in kendisini güvende hissetme yöntemi olmuştur. $\mathrm{Bu}$ dönemde Kuzey Kore ile kurulan ilişkiler ideoloji çerçevesinde şekillenmiştir. Parabellum stratejisi, Soğuk Savaş sonrasında Çin'in uluslararası ortamdan soyutlanması gerçeği ile yüzleşmesine sebep olmuştur.

Konfüçyus-Mencian stratejik kültürü ise, ÇHC'nin Soğuk Savaş sonrası dış politikasında kendini daha fazla belli etmeye başlamıştır. Konfüçyus anlayışının yaratmış olduğu uzlaşmacı olmak, komşularla iyi geçinmek stratejileri Soğuk Savaş sonrasında Çin dış politikasında daha çok uygulama alanı bulmuştur. Özellikle Kore yarımadasına yönelik Çin dış politikasında bu etkiler gözlenmektedir. ÇHC'nin 1992 y1lında Güney Kore ile ilişkileri geliştirmesi, KonfüçyusMencian stratejik kültürünün dış politikaya etkisini göstermesi bağlamında en bariz örneği konumundadır. Bununla birlikte Kuzey Kore ile ilişkilerin Komünist ideoloji perspektifinden çıkmış olduğu gözlenmektedir. Kuzey Kore'de çekilen açlık sıkıntısı Çin'in Kuzey Kore'ye gıda yardımı yapmasını sağlamıştır. Çin'in bu şekilde davranması Konfüçyus-Mencian stratejik kültürünün Çin-Kuzey Kore dış politikasına yansımasını göstermektedir. Çünkü çatışma yönetim stratejilerinin kurumsallaşması daha doğrusu toplum tarafindan kabul edilmesi; toplumsal gelenekler, toplumsal ön kabuller tarafindan desteklenmesi ile mümkündür (Jeon, 2008: 8). Konfüçyus-Mencian stratejik kültürü Çin çatışma yönetimi stratejisinin de temelini oluşturmuştur (Chen, Starosta, 1997-1998: 3).

Çin çatışma yönetimi stratejisinin toplumsal gelişmeler neticesinde ortaya çıkması, Çin çatışma yönetimi stratejisinin Çin toplumu tarafından da içselleştirilmesini sağlamıştır. Bu bağlamda Çin çatışma yönetimi stratejisi, Çin toplumu tarafından kabul edilmiş ilkeler çerçevesinde oluşmuştur. Bundan dolayıdır ki, ÇHC'nin Kuzey Kore'ye yönelik dış politikası 1990 sonrasında Çin çatışma yönetimi stratejisinden etkilenmiş ve kırılgan bir dış politikadan ziyade daha esnek bir şekle bürünmüştür. Buna karşıllk toplumsal değerleri dikkate almayan çatışma yönetimi stratejileri Yugoslavya ve Irak örneğinde olduğu gibi felaketlerle sonuçlanabilmektedir (Ober, 2007: 64).

Çin stratejik kültürünün iki temel parçası olan Parebellum ve Çin çatışma yönetim stratejisi Çin'in Kuzey Kore'ye yönelik dış politikasında dönem dönem çelişkili durumları da beraberinde getirmiştir. Kuzey Kore'nin silahlanması veya nükleer silah elde etme çabası, Çin'in güvenliğini tehdit eden bir unsur olarak algılanmazken, Kuzey Kore'nin ekonomik kriz ve gıda yetersizliği sebebi ile çökmesi yarımadadaki istikrarı bozacağı sebebi ile Çin'in güvenliğini tehdit eden bir unsur olarak görülmesine sebep olabilmektedir. Bu dış politik görünüm çelişkili bir görünüm arz etse de Çin çatışma yönetimi stratejisi bağlamında istikrarın yani uyumun devam edeceği öngörülmüştür.
Sonuç olarak, Çin'in Kuzey Kore'ye yönelik dıș politikası, Çin'in bölgedeki güvenlik hislerine göre şekillenmektedir. Bununla birlikte Çin'in çatışma yönetimi stratejisi 19902000 yılları arasında Çin-Kuzey Kore ile ilişskilerinde oldukça etkili bir konumdadır. Bunun içindir ki Çin, uluslararası toplum ile bütünleşmeyi reddetmemekte ve bölgede meydana gelebilecek Kuzey Kore ve Güney Kore çatışmasını uyumu bozacak en önemli sebep olarak görmektedir. Üstelik Soğuk Savaş'ın yeni bittiği bu dönemde Çin Komünizmin lideri gibi davranmamakta aksine Kuzey Kore ile kurulan ilişkiler Çin'in sınır güvenliğini garanti etmektedir. Ayrıca Çin Kuzey Kore ile kurulan ilișkilerde kendine güvenmekte ve bölge istikrarının korunmasında katkı yapmayı amaçlamaktadır. Yeni dönemde Çin'in saldırgan bir dış politika izlememesi veya ideolojisini yayma gibi bir emelinin olmaması başka bir deyişle yapıcı davranması, Çin çatışma yönetimi stratejisinin Çin dış politikasındaki etkisini göstermektedir.

ÇHC bölgesinde uyuma ve istikrara önem vermektedir bu bağlamda ilerleyen süreçte Kuzey Kore ile Güney Kore arasında yaşanacak bir gerilimde Çin arabulucu olarak rol alabilir. Bunun yanında Çin'in hem Kuzey Kore hem de Güney Kore ile iletişim kanallarını açık tutması ve her firsatta birleşik bir Kore'den yana olduğunu belirtmesi Çin'in imajına olumlu katkı yapmakta ve bölgede kendisine duyulan güveni arttırmaktadır. Dış Politika'da Çin'in çatışma yönetimi stratejisi Çin'e Kuzey Kore ve Güney Kore arasında bir denge çerçevesinde ilişkilerini kurmasını sağlamıştır. İlerleyen dönemde Çin'in yumuşak karnı olmaya aday konu bu dengenin bozulması ihtimalidir.

\section{Notlar}

${ }^{1}$ Jiu Fen: İhtilaf, wenti: problem, chog tu: çatışma, fen gi: fikir ayrılığı anlamında kullanılmaktadır.

${ }^{2} 2016$ yılı verilerine göre Çin'in nüfusu 1,373,541,278'dir, Çin'in 2016 yılı gayri safi yurtiçi hasılası 11.39 tirilyon dolardır.

\section{Kaynakça}

Ahn, Y. (2002). North Korea in 2001: At A Crossroads. Asian Survey, 42(1), 192-197.

Akçadağ, E. (2013). AB Ortak Güvenlik ve Savunma Politikasının Oluşumunda Stratejik Kültürün Etkisi. (Erişim: 17.07.2013) http://www.bilgesam.org/incele/65/-ab-ortak-guvenlikve-savunma-politikasi'nin-olusumunda-stratejikkulturun-onemi/

Akman, H. (2015). Şanghay İşbirliği Örgütü'nün Oluşumunda Rusya-Çin ilişkileri ve İlişkilerin Problemleri. Uluslararası Sosyal Araştırmalar Dergisi, 8(37), 311-326.

Akyeşilmen, N. (2013). Çatışma Yönetimi: Kavramsal ve Kuramsal Bir Analiz. İçinde: Haz. Nezir Akyeşilmen, Barışı Konuşmak. Ankara: ODTÜ Yayınevi.

Burchill, S. (2009). Uluslararası İlişkiler Teorileri. (çev. Ali Aslan, Muhammed Ali Ağcan). İstanbul: Küre Yayınları.

Chen, G. M., \& Starosta, W. J. (1997). Chinese conflict management and resolution: Overview and implications. Intercultural Communication Studies, 7, 1-16. 
Cheng, J. Y. S., \& Zhan, F. W. (2009). Chinese foreign relation strategies under Mao and Deng: a systematic and comparative analysis. Kasarinlan: Philippine Journal of Third World Studies, 14(3), 91-114.

CIA (2017). The World Factbook: China. (Erişim: 22.05.2017),

https://www.cia.gov/library/publications/the-worldfactbook/geos/ch.html

Çınar, Y. (2016). Çatışma Sürecinden Devlet İnşasına: Doğu Timor. Bilge Strateji, 8(15), 85-112.

Dassu, M., \& Tony S. (1992). The Reform decade in China. USA: Routledge Chapman\&Hall Inc.

Dellios, R. (1994). Chinese Strategic Culture: Part 1 - The Heritage from the Past. CEWCES Research Papers. (Erişim: http://epublications.bond.edu.au/cewces_papers/1

Deutsch M. \& Coleman P.T., \& Marcus E. C. (2006). The Handbook of Conflict Resolution Theory and Practice. USA: Jossey Bass.

Faust, J. R., \& Judith F. (1995). China in World Politics. USA: Faust\&Kornberg.

Galtung, J. (2007). Peace by Peaceful Conflict Transformation - the TRANSCEND Approach. Haz. Charles W. Johan G. Handbook of Peace and Conflict Studies, USA: Routledge.

Garret, B. \& Glaser, B. (1995). Chinese Assesments of North Korea. Asian Survey, 35(6), 528-525.

Horward, P. (2004). Why Not Invade North Korea? Threats Language Games and US: Foreign Policy. International Studies Quarterly, 48(4), 805-828.

Jeon, H. W. (2008). Understanding Conflict and Conflict Analysis. California: Sage Publications.

Johnston, A. I. (1998). Cultural Realism Strategic Culture and Grand Strategy in Chinese History. USA: Princeton.

Kang, D. C. (1995). Rethinking North Korea. Asian Survey, 35(3), 253-267.

Kennedy, A. (2012). The International Ambitions of Mao and Nehru National Efficacy Beliefs and the Making of Foreign Policy. UK: Cambridge Pub.

Kim, H. (2017). On China's Internal Stability. (Erişim: 25.01.2017),

https://www.swpberlin.org/fileadmin/contents/products/ projekt_papiere/Kim_ks.pdf

Kim, S. S. (1996). North Korea in 1995, the Crucible of Our Style Socialism. Asian Survey A Survey of Asia in 1995: Part I, 36(1), 1-24.

Ko, C. Y., Koyama, M., \& Sng, T. H. (2018). Unified china and divided Europe. International Economic Review, 59(1), 285-327.

Lee, C. J., \& Hsieh, S. (2001). China's Two-Korea Policy at Trial: The Hwang Chang Yop Crisis. Pacific Affairs, 74(3), 321-341.
Locke, C. A. (2007). Chinese Methods of Interpersonal Conflict Management. Master Thesis. Kansas: School of Advanced Military Studies.

Narayanan, R. (2006). The Politics of Reform in China: Deng, Jiang and Hu. Strategic Analysis, 30(2), 329-353.

Ober, J. (2007). Former Yugoslavia and Iraq: a Comparative Analysis of International Conflict ismanagement. In: Charles Webel \& Johan Galtung (Eds.), Handbook of Peace and Conflict Studies. USA: Routledge.

Oetzel, J. G., \& Ting-Toomey S. (2006). The SAGE handbook of Conflict Communication: Integrating theory, Research and Practice. UK: Sage Pub.

Oh, K., \& Ralf, H. (1999). North Korea between Collapse and Reform. Asian Survey, 39(2), 287-309.

Rockhill, W. W. (1889). Korea in Its Relations with China. Journal of American Oriental Society, 13, 1-33.

Scalapino, R. A. (1963). The Foreign Policy of North Korea. The China Quarterly, 14, 30-50.

Segal, G. (1985). Strategic and Ethnic-chic. International Affairs, 60(1), 15-30.

Shambaugh, D. (2004/2005). China Engages Asia: Reshaping The Regional Order. International Security, 29(3), 64-99.

Shi, T. (1990). The Democratic Movement in China in 1989 Dynamics and Failure. Asian Survey, 30(12), 414-430.

Snyder, S. (2000-2001). North Korea's Challenge of Regime Survival: Internal Problems and Implications for the Future. Pacific Affairs, 73(4), Special Issue: Korea Influx, 517-533.

Sun-Tzu, (2016). Savaş Sanatı. İstanbul: Anahtar Kitap,

Sweda, J. C. (2018). Chinese-North Korean Discourse: Pathways to the Future. The Fletcher School: 2004, thesis Dostupnéna. (Erişim: 12.03.2018), http://fletcher.tufts.edu/research/2004/Sweda-John.pdf

Swope, K. M. A. (2016). Dragon's Head and a Serpent's Tail: Ming China and the First Great East Asian War, 15921598, USA: University of Oklahoma Press.

Tekin, S. (2013). Çatışma Dili: Bir Söylem Analizi. İçinde: (Haz. Nezir Akyeşilmen), Barışı Konuşmak, Ankara: ODTÜ Yayınevi.

The 14th National Congress (2016). The First Plenum of the 14th CPC Central Committee. (Erişim: 22.05.2016), www.bjreview.com.cn/90th/201103/30/content_357540.htm

Unesco Constitution. (2012). (Erişim: 29.01.2012), http://www.unesco.org/education/nfsunesco/pdf/UNES CO_E.PDF.

Varrall, M. (2015). Chinese Worldviews and China's Foreign Policy, Lowy Institute for International Policy, Australia.

Wang, F. L. (1999). Joining The Major Powers For The Status Quo: China's Views and Policy on Korean. Pasific Affairs, 72(2), 167-185. 
Xie, Z. (2011). The Rise of China and Its Growing Role in International Organizations. ICCS Journal of Modern Chinese Studies, 4(1), 85-96.

Yavaş, A. (2017). Kore Sorunu ve Uzak Doğu'da İstikrar Arayışı: Altılı Görüşmeler. (Erişim: 02.06.2017), www.bilgesam.org/Images/Dokumanlar/0-2712014062522asya_bol7.pdf.

Zhao, Q. (1996). Chinese Foreign Policy. New York: Oxford University Press.

Zhao, Q. (2006). China's New Approach to Conflict Management: The Cases of North Korea and Taiwan. China: Silk Road Paper. 